\title{
Erratum to: Accrediting retail drug shops to strengthen Tanzania's public health system: an ADDO case study
}

Edmund Rutta ${ }^{1}$, Jafary Liana ${ }^{2}$, Martha Embrey ${ }^{1 *}$, Keith Johnson', Suleiman Kimatta ${ }^{2}$, Richard Valimba ${ }^{2}$, Rachel Lieber ${ }^{1}$, Elizabeth Shekalaghe ${ }^{3}$ and Hiiti Sillo ${ }^{4}$

Following publication of the original version [1] of the article in the Journal of Pharmaceutical Policy and Practice, it was brought to our attention that the Alliance for Health Policy and Systems Research's support is missing in the acknowledgement section.

The authors would like to add the following text:

"The authors would like to acknowledge the support of the Alliance for Health Policy and Systems Research (HSR/HIS), World Health Organization which supported the development of this case study and publication of this work."

\footnotetext{
Author details

${ }^{1}$ Management Sciences for Health, Arlington, VA, USA. ${ }^{2}$ Management

Sciences for Health, Dar es Salaam, Tanzania. ${ }^{3}$ Pharmacy Council of Tanzania, Dar es Salaam, Tanzania. ${ }^{4}$ Tanzania Food and Drugs Authority, Dar es Salaam, Tanzania.
}

Received: 15 October 2015 Accepted: 16 October 2015

Published online: 19 November 2015

\section{Reference}

1. Rutta E, Liana J, Embrey M, Johnson K, Kimatta S, Valimba R, et al.

Accrediting retail drug shops to strengthen Tanzania's public health system: an ADDO case study. J Pharm Policy Pract. 2015;8:2.

\footnotetext{
* Correspondence: membrey@msh.org

'Management Sciences for Health, Arlington, VA, USA

Full list of author information is available at the end of the article
}

\section{Submit your next manuscript to BioMed Central and take full advantage of:}

- Convenient online submission

- Thorough peer review

- No space constraints or color figure charges

- Immediate publication on acceptance

- Inclusion in PubMed, CAS, Scopus and Google Scholar

- Research which is freely available for redistribution

Submit your manuscript at

www.biomedcentral.com/submit

() Biomed Central 